Check for updates

Cite this: RSC Adv., 2018, 8, 5685

Received 26th December 2017 Accepted 15th January 2018

DOI: $10.1039 / c 7 r a 13603 j$

rsc.li/rsc-advances

\section{Selective removal of lead ions from aqueous solutions using 1,8-dihydroxyanthraquinone (DHAQ) functionalized graphene oxide; isotherm, kinetic and thermodynamic studies $\dagger$}

\author{
Mohammad Khazaei, (DD ab Simin Nasseri, (DD *bc Mohammad Reza Ganjali, de \\ Mehdi Khoobi, (D) ${ }^{\mathrm{f}}$ Ramin Nabizadeh, ${ }^{\text {b }}$ Elham Gholibegloo $^{\mathrm{g}}$ and Shahrokh Nazmarab
}

An anthraquinone - graphene structure was fabricated and applied for the removal of lead(॥) from aqueous solution. The equilibrium occurred in about $10 \mathrm{~min}$ revealing the high adsorption rate at the beginning of the process. The maximum $\mathrm{Pb}(\mathrm{II})$ adsorption capacity of the $\mathrm{Fe}_{3} \mathrm{O}_{4} \mathrm{QDHAQ}$ GO nanocomposite was about $283.5 \mathrm{mg} \mathrm{g}^{-1}$ that was observed at $323 \mathrm{~K}$ and $\mathrm{pH}$ 5.5. The $\mathrm{Pb}(\Perp)$ adsorption ability increased with the increasing $\mathrm{pH}$. The isotherm and kinetic studies indicated that the Sips isotherm model and the linear form of the pseudo-second kinetic model had a better fit with the experimental results. The positive value of $\Delta H^{0}$ indicated endothermic interactions between $\mathrm{Pb}(॥)$ and $\mathrm{Fe}_{3} \mathrm{O}_{4}(\mathrm{DDHAQ} \mathrm{GO}$. The negative $\Delta G^{0}$ indicated that the reactions are spontaneous with a high affinity for $\mathrm{Pb}(॥)$. The positive $\Delta S^{0}$ values indicated increasing randomness at the solid-solute interface during the adsorption process. The selective removal of $\mathrm{Pb}(॥)$ by the nanocomposite confirms the presence of higher-affinity binding sites for $\mathrm{Pb}(॥)$ than $\mathrm{Cd}(॥), \mathrm{Co}(॥), \mathrm{Zn}(॥)$, and $\mathrm{Ni}(॥)$ ions. Furthermore, the $\mathrm{Fe}_{3} \mathrm{O}_{4}$ (aDHAQ_GO nanocomposite revealed an excellent preferential adsorbent for $\mathrm{Pb}(॥)$ spiked in drinking water samples containing natural ion matrices. EDTA-2NA $0.01 \mathrm{~N}$ was found to be a better elution agent than $\mathrm{HCl} 0.1 \mathrm{M}$ for the nanocomposite regeneration. After five adsorption/desorption cycles using EDTA-2NA $0.01 \mathrm{~N}$, more than $84 \%$ of the adsorbed $\mathrm{Pb}(॥)$ was still desorbed in $30 \mathrm{~min}$. Capturing sub-ppm initial concentrations of $\mathrm{Pb}($ II) and the capability to selectively remove lead from drinking water samples make the $\mathrm{Fe}_{3} \mathrm{O}_{4} @ \mathrm{QDHAQ}$ _GO nanocomposite practically convenient for water treatment purposes. High adsorption capacity and facile chemical synthesis route are the other advancements.

\section{Introduction}

Lead ions are a severe environmental concern and can contaminate drinking water resources. ${ }^{\mathbf{1 , 2}}$ The maximum

\footnotetext{
aDepartment of Environmental Health Engineering, School of Public Health and Research Center for Health Sciences, Hamadan University of Medical Sciences, Hamadan, Iran

${ }^{b}$ Department of Environmental Health Engineering, School of Public Health, Tehran University of Medical Sciences, P. O. Box: 14155-6446, Tehran, Iran. E-mail: naserise@tums.ac.ir; Fax: +98 2188950188; Tel: +98 2188954914

${ }^{\prime}$ Center for Water Quality Research, Institute for Environmental Research, Tehran University of Medical Sciences, Tehran, Iran

${ }^{d}$ Center of Excellence in Electrochemistry, Faculty of Chemistry, University of Tehran, Tehran, Iran

${ }^{e}$ Biosensor Research Center, Endocrinology \& Metabolism Molecular-Cellular Sciences Institute, Tehran University of Medical Sciences, Tehran, Iran

${ }^{f}$ Department of Pharmaceutical Biomaterials and Medical Biomaterials Research Center, Faculty of Pharmacy, Tehran University of Medical Sciences, Tehran, Iran ${ }^{g}$ Department of Chemistry, Faculty of Science, University of Zanjan, Zanjan, Iran $\dagger$ Electronic supplementary information (ESI) available. See DOI: $10.1039 / \mathrm{c} 7 \mathrm{ra} 13603 \mathrm{j}$
}

contaminant level (MCL) of $\mathrm{Pb}^{2+}$ for drinking water is $10 \mathrm{ppb}$ set by EPA and national standard organizations. ${ }^{3,4}$ The strict limitations on discharge effluents containing $\mathrm{Pb}^{2+}$ into natural water bodies are due to the high toxicity potential for vital organs such as brain and kidney. ${ }^{2}$

Different methods are currently applied for the removal of high concentrations of lead ion that can be found in industrial wastewaters; $^{5-8}$ whereas only a few methods e.g. using functionalized adsorbents ${ }^{\mathbf{9 , 1 0}}$ and membrane technologies ${ }^{\mathbf{1 1}}$ can be adapted for the capturing of low concentrations (around $1 \mathrm{ppm}$ ) commonly occurring in drinking water sources. Furthermore, avoiding alteration of the natural ion matrices of drinking waters during the removal of a certain target contaminant is a consideration especially for membrane-based water treatment technologies. ${ }^{\mathbf{1 2 , 1 3}}$ New generation adsorbents such as graphene oxide and carbon nanotubes show metal adsorption capacities much more than those of traditional adsorbents. ${ }^{14}$ For example, the ordinary adsorption capacity of activated carbon is less than $70 \mathrm{mg} \mathrm{g}^{-1}$, whereas graphene oxide nanosheets are capable of reaching an adsorption capacity of $4000 \mathrm{mg} \mathrm{g}^{-1} .^{15}$ 
Graphene oxide is an emerging carbon-based nanomaterial that has revealed the promising adsorptive properties. Despite the graphene (G) and reduced graphene oxide (RGO), the graphene oxide (GO) creates a highly stable aqueous dispersion. ${ }^{\mathbf{1 6}}$ This property leads to increase the effective contacts with target contaminants without vigorous mechanical mixing. The dispersability properties of GO is attributed to the plenty hydrophilic functional groups covering the GO flakes. ${ }^{17}$ The GO flake surface contains various functional groups including epoxy and hydroxide, whereas the edge of flakes mainly contains the carboxylic groups. ${ }^{18}$

In recent years, using $\mathrm{Pb}^{2+}$ selective membrane electrodes (ISE) have been extensively studied with different active materials to determine lead ion concentration in water and wastewater. $^{19,20}$ The active materials are mainly consisting of ligands or Schiff bases, which are known as ionophores. ${ }^{21}$ It has been revealed that some ionophores such as anthraquinone, ${ }^{22-24}$ methacrylate,$^{25}$ and nucleic acids ${ }^{26}$ have the selective affinity to lead ion. The main drawback regarding to the most of ionophores is their hydrophobic nature which makes them unusable to create aqueous solution for the lead ion removal. ${ }^{27}$ Using GO flakes as the aqueous dispersion agents can provide an appropriate platform for the attachment of ionophores and producing a water dispersible GO-ionophore composite.

1,8-Dihydroxyanthraquinone (DHAQ), namely Dantron is a dye intermediate and a medicine. ${ }^{27,28}$ Furthermore, some works report the high affinity of DHAQ as a ligand to form stable complexes with $\mathrm{Pb}^{2+}{ }^{20,24}$ In this study, DHAQ was used as an ionophore agent in the structure of $\mathrm{Fe}_{3} \mathrm{O}_{4} @ \mathrm{SiO}_{2}-\mathrm{GO}$ to form the $\mathrm{Fe}_{3} \mathrm{O}_{4} @$ DHAQ_GO nanocomposite and aimed to have $\mathrm{Pb}^{2+}$ selective removal property from aqueous solutions.

\section{Materials and methods}

\subsection{Materials}

Graphite powder (particle size $20 \mu \mathrm{m}$ ), tetraethyl orthosilicate (TEOS), (3-aminopropyl) triethoxysilane (APTES), $n$-hydroxysuccinimide (NHS), 1-ethyl-3-(3-dimethyl aminopropyl) carbodiimide (EDC $\cdot \mathrm{HCl}$ ), and 1,8-dihydroxyanthraquinone (DHAQ) were purchased from Sigma-Aldrich, Ltd. Co. All other chemicals such as sodium nitrate $\left(\mathrm{NaNO}_{3}\right)$, potassium permanganate $\left(\mathrm{KMnO}_{4}\right)$, sulfuric acid $\left(\mathrm{H}_{2} \mathrm{SO}_{4}\right)$, hydrochloric acid $(\mathrm{HCl})$, hydrogen peroxide aqueous solution $\left(\mathrm{H}_{2} \mathrm{O}_{2}\right)$, iron chloride hexahydrate $\left(\mathrm{FeCl}_{3}, 6 \mathrm{H}_{2} \mathrm{O}\right)$, and iron chloride tetrahydrate $\left(\mathrm{FeCl}_{2}, 4 \mathrm{H}_{2} \mathrm{O}\right)$ were of reagent grade and used without further purification.

\subsection{Preparation of $\mathrm{Fe}_{3} \mathrm{O}_{4} @ \mathrm{SiO}_{2}$ GO}

Our previous work reported the fabrication of graphene oxide (GO), $\mathrm{Fe}_{3} \mathrm{O}_{4}$ magnetic nanoparticles, $\mathrm{Fe}_{3} \mathrm{O}_{4} @ \mathrm{SiO}_{2} \mathrm{NH}_{2}$ nanoparticles, and $\mathrm{Fe}_{3} \mathrm{O}_{4} @ \mathrm{SiO}_{2} \mathrm{GO}$ nanocomposite. ${ }^{1}$ The preparation of GO was based on using sulfuric acid as digestion agent, and $\mathrm{H}_{2} \mathrm{O}_{2}$ for the oxidation of graphite. ${ }^{29}$ Co-precipitation method was used to prepare $\mathrm{Fe}_{3} \mathrm{O}_{4}$ magnetic nanoparticles. ${ }^{30}$ Then, $\mathrm{NH}_{2}$-groups were applied as linkers to create covalent bonds between $\mathrm{Fe}_{3} \mathrm{O}_{4}$ magnetic nanoparticles and GO.
Consequently, covering APTES and TEOS on the $\mathrm{Fe}_{3} \mathrm{O}_{4}$ magnetic nanoparticles produces $\mathrm{Fe}_{3} \mathrm{O}_{4} @ \mathrm{SiO}_{2} \mathrm{NH}_{2} \cdot{ }^{31,32}$ Finally, a condensation reaction between the carboxylic groups (COO-) of $\mathrm{GO}$ and the amine groups $\left(\mathrm{NH}_{2}-\right)$ of $\mathrm{Fe}_{3} \mathrm{O}_{4} @ \mathrm{SiO}_{2}$ was prepared for the fabrication of $\mathrm{Fe}_{3} \mathrm{O}_{4} @ \mathrm{SiO}_{2} \mathrm{GO}$ nanocomposite. ${ }^{32}$

\subsection{Preparation of $\mathrm{Fe}_{3} \mathrm{O}_{4} @ D H A Q \_G O$}

$200 \mathrm{mg}$ DHAQ was added into $50 \mathrm{~mL}$ DMF followed by mild stirring for 3 hours. Then, $200 \mathrm{mg}$ EDS and $100 \mathrm{mg}$ NHS were added and $\mathrm{pH}$ was adjusted between 4 to 6 followed by vigorous mixing for 2 hours at room temperature. After that, $0.5 \mathrm{~g} \mathrm{Fe}_{3}$ $\mathrm{O}_{4} @ \mathrm{SiO}_{2}$ GO was dispersed into the mixture and mixing was continued up to 12 hours. Finally, dispersed solid was separated via centrifuge (12 $000 \mathrm{rpm}, 10 \mathrm{~min})$, washed with deionized water, and dried to obtain $\mathrm{Fe}_{3} \mathrm{O}_{4} @ D H A Q \_G O$. Schematic of the synthesis path applied for the fabrication of $\mathrm{Fe}_{3} \mathrm{O}_{4} @ D H A Q$ GO nanocomposite was presented in Fig. 1. As revealed, 1,8-dihydroxyanthraquinone attaches to amine group linked with $\mathrm{Fe}_{3} \mathrm{O}_{4}$ nanoparticle.

\subsection{Instrumentation}

The prepared nanocomposite was characterized applying SEM (MIRA3, TESCAN®, Czech), AFM (SPM, VEECO®, USA), FTIR (Spectrum One, Perkin-Elmer ${ }^{\circledR}$, USA), XRD (Philips ${ }^{\circledR}$, Netherlands), UV-Visible spectrophotometer (Perkin-Elmer ${ }^{\circledR}$, USA), TEM (EM900, Zeiss®, Germany), TGA (TGA 4000, PerkinElmer®, USA), and pHpzc. The initial and final concentration of $\mathrm{Hg}$ (II) were measured by using an ICP-OES (ARCOS, SPECTRO®, Germany). pH was adjusted by using a MITEC-965 (micra®, India) $\mathrm{pH}$ meter. A thermostatic shaker (Innova 4340, Eppendorf, Germany) was used to study the batch experiments.

\subsection{Characterization}

A Hitachi-S4160 scanning microscope were used to provide SEM images (Tokyo, Japan). The AFM measurements were obtained by using a Nanoscope $\mathrm{V}$ multimode atomic force microscope (Veeco Instruments, USA). Samples prepared for the AFM measurements contained dispersions of $\mathrm{GO} /$ methanol solutions $\left(70 \mathrm{mg} \mathrm{mL}{ }^{-1}\right.$ ) smeared on a fresh mica surface and allowed drying in the air. ${ }^{33}$

\subsection{Adsorption experiments}

A typical adsorption experiment was established by adding 10 mg $\mathrm{Fe}_{3} \mathrm{O}_{4} @ D H A Q \_G O$ into a $100 \mathrm{~mL}$ solution containing $\mathrm{Pb}^{2+}$ ions at room temperature. Varied initial concentrations of $\mathrm{Pb}^{2+}$, from $1 \mathrm{mg} \mathrm{L}^{-1}$ to $10 \mathrm{mg} \mathrm{L} \mathrm{L}^{-1}$, were used and for all the $\mathrm{Pb}^{2+}$ aliquots, the pH value was kept on 7 applying buffer solutions. The mixing rate was constant at $150 \mathrm{rpm}$ for the all solutions.

An external magnetic field was used for the removal of adsorbent after the adsorption time. The equilibrium adsorption capacity $\left(q_{\mathrm{e}}, \mathrm{mg} \mathrm{g}^{-1}\right)$ of $\mathrm{Pb}^{2+}$ was determined by the following equation.

$$
q_{\mathrm{e}}=\frac{\left(C_{0}-C_{\mathrm{e}}\right) \times V}{x_{\mathrm{ads}}} \times 1000
$$




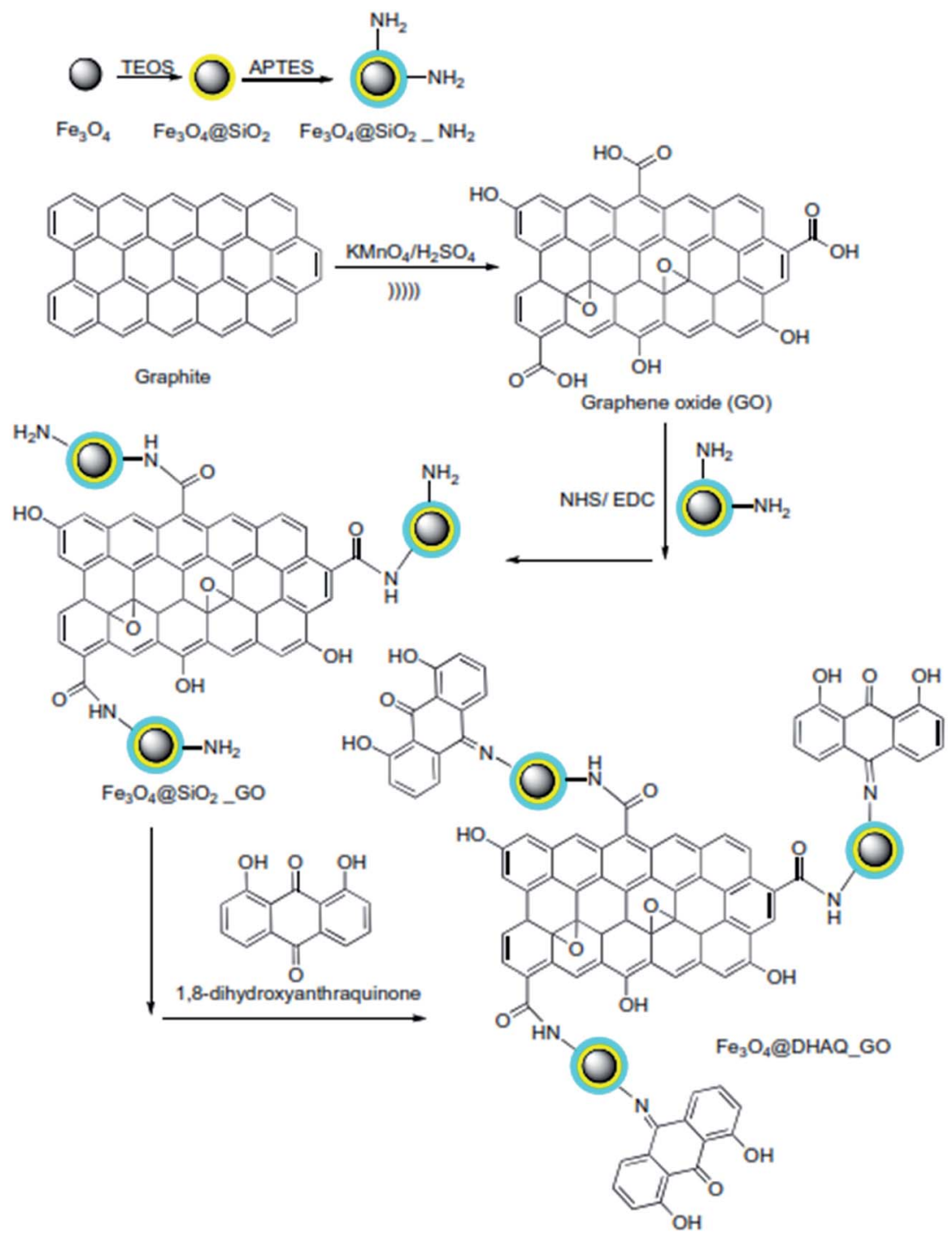

Fig. 1 Schematic of the chemical path to synthesis $\mathrm{Fe}_{3} \mathrm{O}_{4}(\mathrm{aDHAQ} \mathrm{GO}$ nanocomposite.

where, $C_{0}$ and $C_{t}$ are the $\mathrm{Pb}^{2+}$ initial and final concentrations $\left(\mathrm{mg} \mathrm{L}^{-1}\right), x_{\text {ads }}$ is the adsorbent mass $(\mathrm{g}), V$ is the reactor volume $(\mathrm{L})$, and 1000 is a conversion factor.

A Spectro Arcos ICP-optical emission spectrometer (SPECTRO Analytical Instruments, Kleve, Germany) was used for the measurement of $\mathrm{Pb}^{2+}$ concentrations.

The parameters of isotherm and kinetic equations were determined by applying Solver engine of Microsoft Excel spreadsheet software ${ }^{34}$ based on nonlinear forms of the equations.

\subsection{Selectivity study}

Two independent studies were conducted to investigate the capability of $\mathrm{Fe}_{3} \mathrm{O}_{4} @$ DHAQ_GO nanocomposite for the selective capturing of $\mathrm{Pb}^{2+}$ from water: binary ion study; including aliquots contained binary ion matrices $\left(\mathrm{Pb}^{2+} / \mathrm{Cu}^{2+}\right.$, $\mathrm{Pb}^{2+} / \mathrm{Cd}^{2+}, \mathrm{Pb}^{2+} / \mathrm{Zn}^{2+}$, and $\left.\mathrm{Pb}^{2+} / \mathrm{Co}^{2+}\right)$ and selective removal of $\mathrm{Pb}^{2+}$ from natural water samples; including drinking water samples spiked with $\mathrm{Pb}^{2+}$ ions. The concentration of metal ions was measured by using ICP-OES. The distribution coefficient $K_{\mathrm{d}}\left(\mathrm{mL} \mathrm{g}^{-1}\right)$, selectivity coefficient $k$, and the relative selectivity coefficient $k$ were determined by eqn (2)-(4), respectively.

$$
\begin{gathered}
K_{\mathrm{d}}=\frac{\left(C_{\mathrm{i}}-C_{\mathrm{f}}\right) V}{C_{\mathrm{f}} W} \\
k=\frac{K_{\mathrm{d}(\mathrm{Pb}(\mathrm{II}))}}{K_{\mathrm{d}(\mathrm{M}(\mathrm{II}))}} \\
k^{\prime}=\frac{k_{\mathrm{MGO}-\mathrm{DHAQ}}}{k_{\mathrm{MGO}}}
\end{gathered}
$$

where, $C_{\mathrm{i}}$ and $C_{\mathrm{f}}$ are the initial and final concentrations of metal ions, respectively. $K_{\mathrm{d}(\mathrm{Pb}(\mathrm{II}))}$ and $K_{\mathrm{d}(\mathrm{M}(\mathrm{II}))}$ are the distribution coefficient of $\mathrm{Pb}^{2+}$ and metal (M) ions, respectively. $k_{\mathrm{MGO}}$-DHAQ and $k_{\mathrm{MGO}}$ are the selectivity coefficient of $\mathrm{Fe}_{3} \mathrm{O}_{4} @$ DHAQ_GO and $\mathrm{Fe}_{3} \mathrm{O}_{4} @ \mathrm{SiO}_{2}-\mathrm{GO}$, respectively. 


\subsection{Desorption and regeneration}

$\mathrm{Pb}^{2+}$ in solution $\left(25 \mathrm{~mL}, 2.45 \mathrm{mg} \mathrm{\textrm {L } ^ { - 1 }}\right.$ ) was adsorbed onto $\mathrm{Fe}_{3^{-}}$ $\mathrm{O}_{4} @$ DHAQ_GO $\left(30 \mathrm{mg} \mathrm{\textrm {L } ^ { - 1 }}\right)$ at $\mathrm{pH} 7$ for $1 \mathrm{~h}$ and then the adsorbents were separated by applying an external magnetic field and the residual quantity of metal ions was determined by ICP-OES. After that, the adsorbents were regenerated in $25 \mathrm{~mL}$ Erlenmeyer flask containing $10 \mathrm{~mL} 0.02 \mathrm{~mol} \mathrm{~L}^{-1}$ eluent to completely leach metal ions at room temperature for $6 \mathrm{~h}$. The concentration of metal ions released from adsorbent into the aqueous phase was measured by ICP-OES. Desorption ratio $(D)$ was determined by using the following equation:

$$
D(\%)=\frac{H_{\mathrm{de}}}{H_{\mathrm{ad}}} \times 100
$$

where, $H_{\mathrm{de}}\left(\mathrm{mg} \mathrm{L}^{-1}\right)$ is the amount of metal ion desorbed into the elution medium. $H_{\text {ad }}\left(\mathrm{mg} \mathrm{L}^{-1}\right)$ is the amount of metal ion adsorbed onto the $\mathrm{Fe}_{3} \mathrm{O}_{4} @ D H A Q \_G O$ nanocomposite.

\section{Results and discussion}

It is well known that various derivatives of anthraquinone are able to form stable complexes with a variety of metal ions in some non-aqueous solvents ${ }^{35,36}$ and anthraquinone-lead(II) complexes are among the most stable ones. ${ }^{37,38}$ Applying the graphene oxide provides the active sites for the anthraquinone that can be covalently bonded and produced a hydrophilic property which is appropriate for the adsorption of $\mathrm{Pb}^{2+}$ in the aqueous solution.

\subsection{Characterization studies}

The FT-IR spectra for GO, $\mathrm{Fe}_{3} \mathrm{O}_{4} @ \mathrm{SiO}_{2}-\mathrm{GO}$, and $\mathrm{Fe}_{3} \mathrm{O}_{4} @$ @DHAQ_GO are presented in Fig. 2. The stretchings $\mathrm{C}-\mathrm{O}$ $\left(1055 \mathrm{~cm}^{-1}\right), \mathrm{C}-\mathrm{OH}\left(1226 \mathrm{~cm}^{-1}\right), \mathrm{C}-\mathrm{O}$ carbonyl $\left(1733 \mathrm{~cm}^{-1}\right)$, and $\mathrm{O}-\mathrm{H}$ hydroxide $\left(3419 \mathrm{~cm}^{-1}\right)^{39-41}$ can be observed in the FT-IR

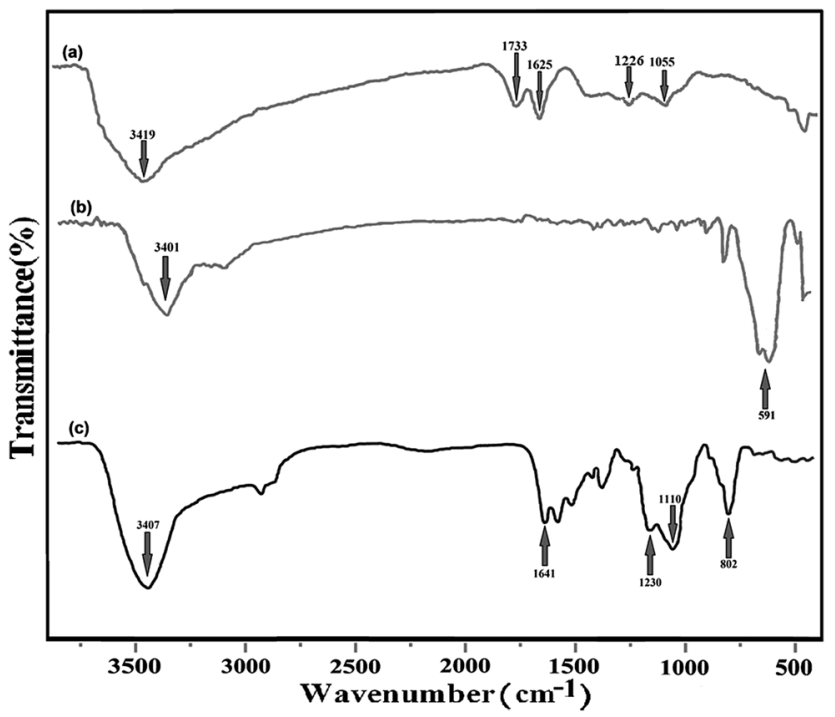

Fig. 2 FT-IR spectra of $\mathrm{GO}$ (a), $\mathrm{Fe}_{3} \mathrm{O}_{4}\left(\mathrm{aSiO}_{2}-\mathrm{GO}\right.$ (b), and $\mathrm{Fe}_{3} \mathrm{O}_{4} \mathrm{a}$ $D H A Q \_G O(c)$. spectrum of GO (Fig. 2(a)). The stretching assigned to the adsorbed water molecules is observed at $1621 \mathrm{~cm}^{-1}$ assigning also to the skeletal vibrations of un-oxidized graphite. ${ }^{\mathbf{4 2 , 4 3}}$

In Fig. 2(b), the spectrum of $\mathrm{Fe}_{3} \mathrm{O}_{4} @ \mathrm{SiO}_{2}-\mathrm{GO}$ is depicted. It shows the vibration of $\mathrm{Fe}-\mathrm{O}$ stretching at $591 \mathrm{~cm}^{-1}$ and an intense stretching around $3400 \mathrm{~cm}^{-1}$. Although, it can be attributed to the remaining water on the surfaces of $\mathrm{Fe}_{3} \mathrm{O}_{4}$ nanoparticles. ${ }^{\mathbf{4 4}}$

Fig. 2(c) depicts the FT-IR spectrum of $\mathrm{Fe}_{3} \mathrm{O}_{4} @ D H A Q$ GO. As shown, a vibration is observed at $3401 \mathrm{~cm}^{-1}$ assigning to the $\mathrm{N}-\mathrm{H}$ stretching. Furthermore, the peak at $1733 \mathrm{~cm}^{-1}$, observed in Fig. 2(a), is disappeared and a new wide peak of $\mathrm{C}=\mathrm{N}$ stretching is appeared at $1641 \mathrm{~cm}^{-1}$. The vibration of $\mathrm{C}-\mathrm{N}$ stretching is appeared at $1230 \mathrm{~cm}^{-1} .^{45}$ The obvious peaks at 802 and $1110 \mathrm{~cm}^{-1}$ can be attributed to the $\mathrm{Si}-\mathrm{O}$ vibrations. The FTIR spectra confirmed that APTES functionalized $\mathrm{Fe}_{3} \mathrm{O}_{4}$ has been bonded covalently to GO nanosheets via the amide linkage. ${ }^{46}$

Fig. S1† depicts field emission SEM images of GO, $\mathrm{Fe}_{3} \mathrm{O}_{4} @$ $\mathrm{SiO}_{2}-\mathrm{GO}$, and $\mathrm{Fe}_{3} \mathrm{O}_{4} @ \mathrm{DHAQ} \mathrm{GO}$ nanoparticles. From Fig. S1(a), $\dagger$ it can be observed that GO is partially transparent and 2- or 3-layered graphene oxides are formed. ${ }^{47,48}$ From Fig. $\mathrm{S} 1(\mathrm{~b}), \dagger$ the spherical $\mathrm{Fe}_{3} \mathrm{O}_{4} @ \mathrm{SiO}_{2}-\mathrm{NH}_{2}$ nanoparticles having 50-60 nm diameters are identified, which finally have been enveloped by GO layers producing aggregated morphologies of $\mathrm{Fe}_{3} \mathrm{O}_{4} @ D H A Q \_G O$ as shown in Fig. S1(c) †.

Fig. 3 illustrates the tapered mode AFM topography scan. A single platelet of GO laid on a freshly cleaved mica surface can be observed in Fig. 3(a) and (b) represents a frequency histogram of platelets thicknesses having the mean thickness of $3.21 \mathrm{~nm}$. Height profile of the green line (Line 1 in Fig. 3(a)) presents a height of $0.732 \mathrm{~nm}$ in cross-section A-A as shown in Fig. 3(c).

Fig. $\mathrm{S} 2 \uparrow$ presents thermal gravimetric analysis (TGA) of $\mathrm{Fe}_{3} \mathrm{O}_{4}$ magnetic nanoparticles, $\mathrm{Fe}_{3} \mathrm{O}_{4} @ \mathrm{SiO}_{2}-\mathrm{GO}, \mathrm{Fe}_{3} \mathrm{O}_{4} @ D H A Q \_G O$, and graphene oxide. As revealed, major weight losses were occurred between 150 and $350{ }^{\circ} \mathrm{C}$ attributing to $\mathrm{CO}, \mathrm{CO}_{2}$ released from labile functional groups. ${ }^{48,49}$ Slower rate of mass loss was detected between 350 and $650{ }^{\circ} \mathrm{C}$ assigning to the removal of some stable oxygenated functional groups. Similar trends of weight loss were observed in $\mathrm{Fe}_{3} \mathrm{O}_{4} @ \mathrm{SiO}_{2}-\mathrm{GO}$ and $\mathrm{Fe}_{3} \mathrm{O}_{4} @$ @HAQ_GO. The $\mathrm{Fe}_{3} \mathrm{O}_{4} @$ @DAQ_GO weight loss was $13.5 \%$ more than those of $\mathrm{Fe}_{3} \mathrm{O}_{4} @ \mathrm{SiO}_{2}-\mathrm{GO}$ in $740{ }^{\circ} \mathrm{C}$ attributing to the presence of 1,8-dihydroxyanthraquinone in the structure of $\mathrm{Fe}_{3} \mathrm{O}_{4}$ @DHAQ_GO. ${ }^{50}$

Fig. S3 $\uparrow$ shows the XRD patterns of $\mathrm{GO}$ and $\mathrm{Fe}_{3} \mathrm{O}_{4} @ \mathrm{SiO}_{2}-\mathrm{GO}$. GO sharp diffraction peaks observable at $2 \theta=12.24^{\circ}$ and $42.83^{\circ}$ are attributed to the reflections of (002) and (101), respectively. Furthermore, six typical peaks at about $2 \theta=30.4$, 35.6, 43.1, 54.1, 57.7 and $62.5^{\circ}$ are observed for $\mathrm{Fe}_{3} \mathrm{O}_{4} @ \mathrm{SiO}_{2}-\mathrm{GO}$, attributing to indices (220), (311), (400), (422), (511) and (440), respectively. Appropriate match of intensities and positions of above mentioned diffraction peaks confirming by pure magnetite JCPDS card (75-1610). ${ }^{51}$ As represented in XRD patterns corresponding to $\mathrm{Fe}_{3} \mathrm{O}_{4} @ \mathrm{SiO}_{2}-\mathrm{GO}$, the reflection peak (002) belonging to GO was disappeared. It is assumed that the 


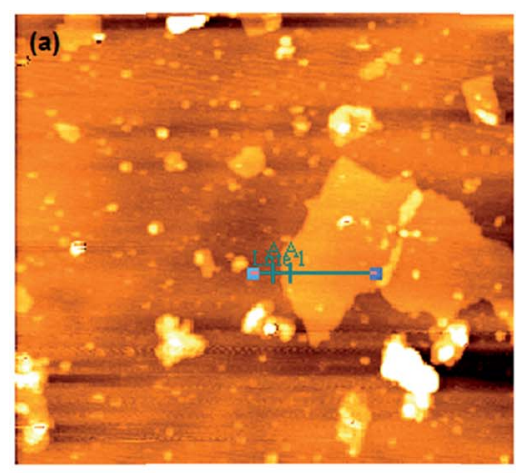

(b)
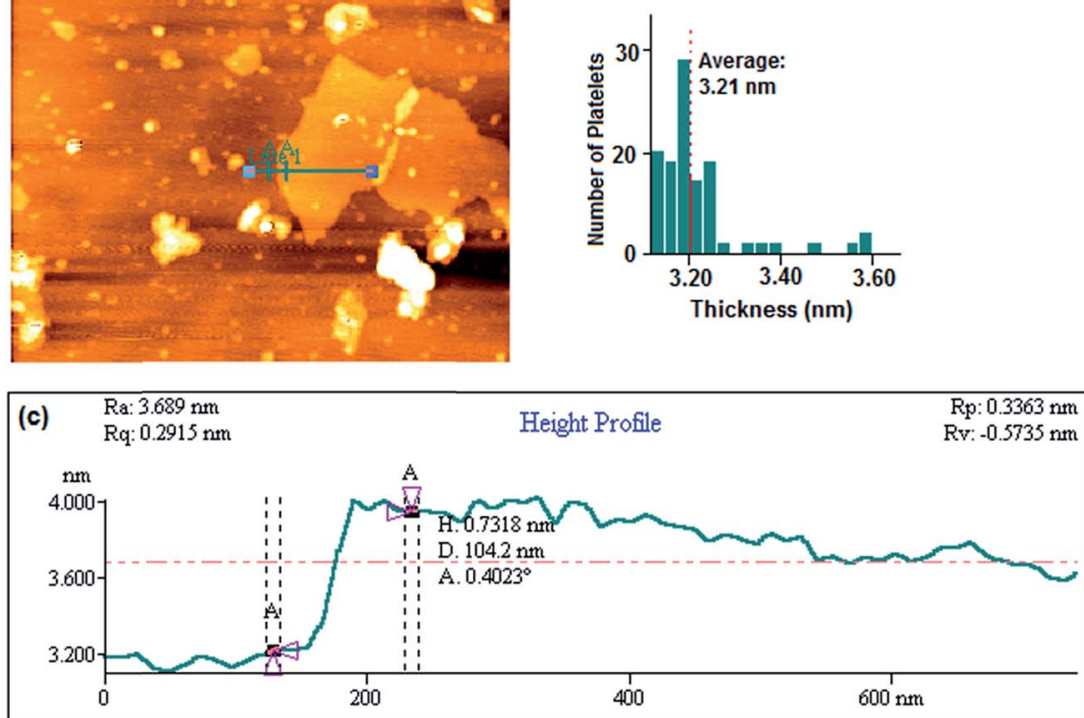

Fig. 3 Tapered mode AFM topography scan. Exfoliated graphene oxide deposited on a freshly cleaved mica surface (a), histogram of platelet thicknesses from images of 138 platelets (the mean thickness is $3.21 \mathrm{~nm}$ ) (b), height profile through the green line (Line 1) presented in (a). Crosssection A-A through the sheet shown in (a) exhibiting a height of $0.732 \mathrm{~nm}$ (c).

GO sheets cover the $\mathrm{Fe}_{2} \mathrm{O}_{3}$ nanoparticles and it hinders the stacking of sheets to create a crystalline arrangement. ${ }^{52}$

The vibration sample magnetization (VSM) was used to determine the magnetic characteristics of fabricated materials contained $\mathrm{Fe}_{3} \mathrm{O}_{4}$. Fig. $\mathrm{S} 4 \uparrow$ shows that the maximum saturation magnetizations of $\mathrm{Fe}_{3} \mathrm{O}_{4} \mathrm{NPs}, \mathrm{Fe}_{3} \mathrm{O}_{4}$-APTES, $\mathrm{GO} @ \mathrm{SiO}_{2}-\mathrm{Fe}_{3} \mathrm{O}_{4}$, and $\mathrm{Fe}_{3} \mathrm{O}_{4} @$ DHAQ_GO were 53.2, 40.1, 19.7, and $13.5 \mathrm{emu} \mathrm{g}^{-1}$, respectively. Decreasing the maximum saturation magnetizations can be ascribed to the $\mathrm{Fe}_{3} \mathrm{O}_{4}$ nanoparticles covering consecutively by APTES, $\mathrm{SiO}_{2}-\mathrm{GO}$, and DHAQ.

Fig. 4 presents the nitrogen adsorption isotherm of $\mathrm{Fe}_{3}$ $\mathrm{O}_{4} @$ @HAQ_GO nanocomposite. The surface area of $215 \mathrm{~m}^{2} \mathrm{~g}^{-1}$ was obtained that is relatively lowered than those reported for pristine GO. ${ }^{53}$ It seems that the agglomeration of $\mathrm{Fe}_{3} \mathrm{O}_{4}$ NPs and

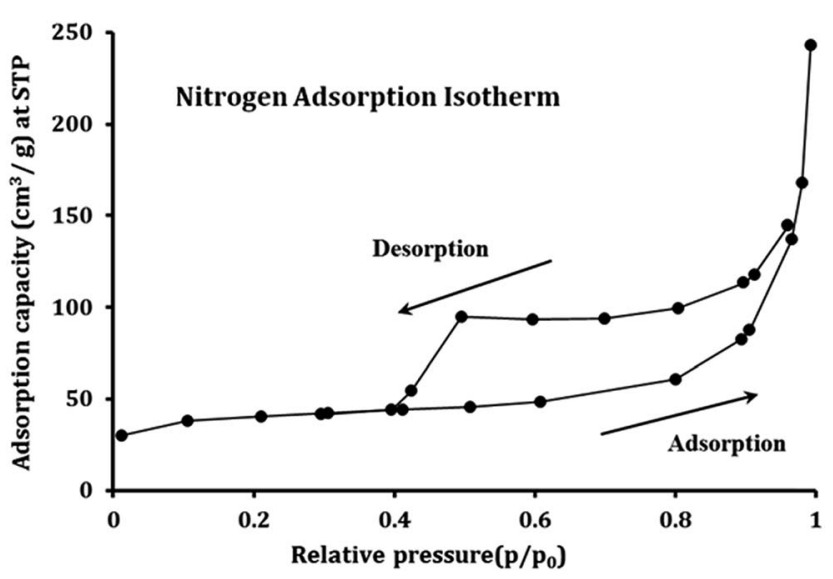

Fig. 4 Nitrogen adsorption-desorption isotherms for $\mathrm{Fe}_{3} \mathrm{O}_{4} \mathrm{a}$ DHAQ_GO nanocomposite.
GO nanosheets tend to an shrinking effect on the GO nanosheets causing the decrease of free surface area $^{48}$ as observed in Fig. S1. $\dagger$ The average pore size of $\mathrm{Fe}_{3} \mathrm{O}_{4}$ @DHAQ_GO was determined to be about $9.26 \mathrm{~nm}$ identifying the mesopore structure of the adsorbent.

\subsection{Adsorption experiments}

3.2.1. Adsorption isotherm. The isotherm models Langmuir (eqn (6)), Freundlich (eqn (7)), and Sips (eqn (8)) were applied to investigate the effect of equilibrium concentrations of $\mathrm{Pb}^{2+}\left(C_{\mathrm{e}}\right)$ on the equilibrium adsorption capacities $\left(q_{\mathrm{e}}\right)$ of $\mathrm{Fe}_{3} \mathrm{O}_{4}$ @DHAQ_GO nanocomposite.

$$
\begin{gathered}
q_{\mathrm{e}}=\frac{q_{\mathrm{m}} K_{\mathrm{L}} C_{\mathrm{e}}}{1+K_{\mathrm{L}} C_{\mathrm{e}}} \\
q_{\mathrm{e}}=K_{\mathrm{f}} C_{\mathrm{e}}^{1 / n_{\mathrm{F}}} \\
q_{\mathrm{e}}=\frac{q_{\mathrm{m}}\left(K_{\mathrm{S}} C_{\mathrm{e}}\right)^{n_{\mathrm{S}}}}{1+\left(K_{\mathrm{S}} C_{\mathrm{e}}\right)^{n_{\mathrm{S}}}}
\end{gathered}
$$

where, $K_{\mathrm{L}}$ is the Langmuir adsorption constant $\left(\mathrm{L} \mathrm{mg}^{-1}\right)$ and $q_{\mathrm{m}}$ represents the maximum adsorption capacity attributing to the complete monolayer coverage of the adsorbent $\left(\mathrm{mg} \mathrm{g}^{-1}\right)$. Furthermore, $K_{\mathrm{F}}\left(\mathrm{mg} \mathrm{g}^{-1}\right)$ and $n_{\mathrm{F}}$ (unit less) are the Freundlich constants. $K_{\mathrm{S}}\left(\mathrm{L} \mathrm{g}^{-1}\right)$ and $n_{\mathrm{S}}$ are the Sips equation parameters denoting the affinity constant and surface heterogeneity, respectively. ${ }^{54,55}$

As represented from Table 1 , the $R^{2}$ values indicated that Sips model has better fit with the experimental results then Langmuir and Freundlich models. Fig. 5 depicts the nonlinear functions of Sips model fitted to the experimental points obtained from the batch studies in different temperatures. 
Table 1 Model parameters obtained from non-linear fitting the experimental equilibrium data with the isotherm models (adsorbent dosage $55 \mathrm{mg} \mathrm{L}^{-1}, \mathrm{pH} 7$, contact time $60 \mathrm{~min}$ )

\begin{tabular}{|c|c|c|c|c|c|c|c|c|c|c|c|}
\hline$T(\mathrm{~K})$ & $q_{\exp }\left(\mathrm{mg} \mathrm{g}^{-1}\right)$ & $q_{\mathrm{m}}\left(\mathrm{mg} \mathrm{g}^{-1}\right)$ & $K_{\mathrm{L}}$ & $R_{\mathrm{L}}^{2}$ & $n_{\mathrm{F}}$ & $K_{\mathrm{F}}$ & $R_{\mathrm{F}}^{2}$ & $q_{\mathrm{m}}\left(\mathrm{mg} \mathrm{g}^{-1}\right)$ & $K_{\mathrm{S}}$ & $n_{\mathrm{S}}$ & $R^{2}$ \\
\hline 293 & 141 & 239.4 & 0.59 & 0.96 & 1.7 & 85.3 & 0.96 & 142.5 & 1.24 & 1.69 & 0.98 \\
\hline 308 & 152 & 225.3 & 1.17 & 0.93 & 2.01 & 114 & 0.93 & 151.6 & 2.12 & 2.36 & 0.99 \\
\hline 323 & 163 & 243.1 & 1.54 & 0.93 & 1.96 & 142 & 0.93 & 164.3 & 3.06 & 2.38 & 0.99 \\
\hline
\end{tabular}

The Sips equation containing three parameters having the capability to apply for both the homogeneous and heterogeneous systems. ${ }^{56}$ The surface heterogeneity of adsorbent should be considered if the deviation of $n_{\mathrm{S}}$ values from 1 is observed. ${ }^{55,57}$ However, the Sips isotherm reach a constant level at high concentrations while a pattern of Freundlich model can be observed at low concentrations. ${ }^{57}$

As revealed from Table 1 , the $\mathrm{Pb}^{2+}$ adsorption capacities of $\mathrm{Fe}_{3} \mathrm{O}_{4} @$ DHAQ_GO nanocomposite were increased by the increasing of temperature assigning to decrease water viscosity along with the increasing of $\mathrm{Pb}^{2+}$ collisions between the sites of nanocomposite and $\mathrm{Pb}^{2+}$ ions. The maximum adsorption capacities $\left(q_{\mathrm{m}}\right)$ obtained by Langmuir isotherm were overestimated (e.g. 243.1 in $323 \mathrm{~K}$ ) while those of Sips model (e.g. 164.3 in $323 \mathrm{~K}$ ) represents a good fit to the experimental data (also, see Fig. 5) which can be due to the heterogeneity characteristic considered in the Sips model. ${ }^{58}$ Increasing the deviations of $n_{\mathrm{S}}$ and $n_{\mathrm{F}}$ values from unity can be assigned to develop the nanocomposite surface heterogeneity over raising the temperature. ${ }^{57}$

3.2.2. Kinetic studies. The sorption capacities $\left(q_{t}\right)$ of $\mathrm{Fe}_{3}$ $\mathrm{O}_{4}$ @DHAQ_GO exposed with $\mathrm{Pb}^{2+}$ initial concentrations 2.5, 5, and $10 \mathrm{mg} \mathrm{L}^{-1}$ were studied over corresponding times. The kinetic models; Lagergren-first-order (eqn (9)) and pseudosecond-order (eqn (10)) were applied for determining the appropriate function to describe the kinetic behavior of the batch systems.

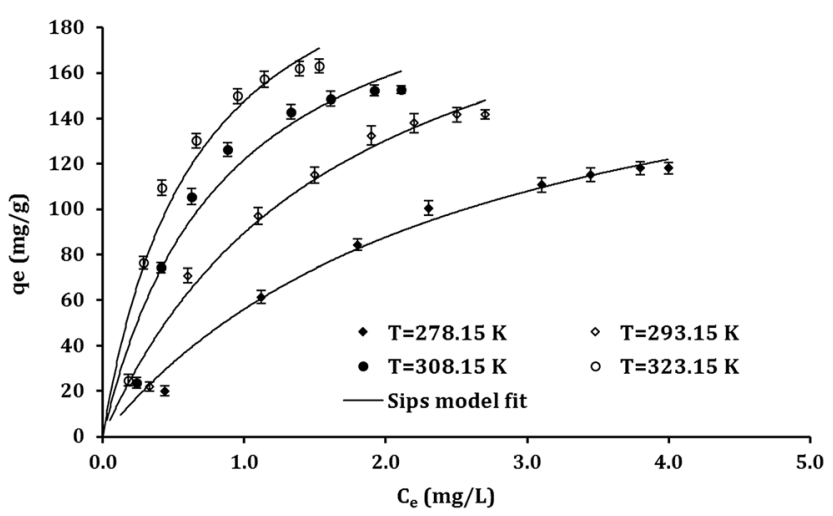

Fig. 5 Adsorption isotherms of $\mathrm{Pb}^{2+}$ on $\mathrm{Fe}_{3} \mathrm{O}_{4} @ \mathrm{QDHAQ} \mathrm{GO}$ nanocomposite at different temperatures. (Adsorbent dosage $100 \mathrm{mg} \mathrm{L}^{-1}$; volume of solution $100 \mathrm{~mL} ; \mathrm{pH} 7 ; \mathrm{Pb}^{2+}$ initial concentration range 1$10 \mathrm{mg} \mathrm{L}^{-1}$ ). Points: experimental data at given temperature, lines: Sips model.

$$
\begin{gathered}
q_{t}=q_{\mathrm{e}}\left(1-\exp \left(-k_{1} \mathrm{t}\right)\right) \\
q_{\mathrm{t}}=\frac{K_{2} q_{\mathrm{e}}{ }^{2} t}{1+q_{\mathrm{e}} k_{2} t}
\end{gathered}
$$

where, $q_{t}$ and $q_{\mathrm{e}}$ are the sorption capacity $\left(\mathrm{mg} \mathrm{g}^{-1}\right)$ at time $t$ and at the equilibrium time, respectively. $k_{1}$ and $k_{2}$ correspond to the pseudo-first-order and pseudo-second-order rate constants, respectively. ${ }^{59,60}$

Fig. 6 illustrates fitting the non-linear forms of pseudosecond kinetic model to the experimental points. As shown, the equilibrium was took place sooner for the batch systems underwent lower $\mathrm{Pb}^{2+}$ initial concentrations.

Table $\mathrm{S} 1 \uparrow$ presents kinetic parameters of $\mathrm{Pb}^{2+}$ removal obtained by using the non-linear forms of pseudo-first and pseudo-second kinetic models (eqn (9) and (10)). As found in Table S1, $\uparrow$ according to the $R^{2}$ values, the pseudo-second model has better fit to the experimental points and $K_{2}$ are increased by increasing the temperature, both are the evidences favor the chemisorption occurring. ${ }^{61-63}$

3.2.3. Thermodynamic parameters. Changing in free energy $\left(\Delta G^{0}\right)$, enthalpy $\left(\Delta H^{0}\right)$, and entropy $\left(\Delta S^{0}\right)$ can be determined by the following equations:

$$
\begin{gathered}
\Delta G^{0}=-R T \ln K_{\mathrm{c}} \\
\ln K_{\mathrm{c}}=-\frac{\Delta G^{0}}{R T}=-\frac{\Delta H^{0}}{R T}+\frac{\Delta S^{0}}{R}
\end{gathered}
$$

where, $R$ is the gas constant $\left(8.314 \mathrm{~J} \mathrm{~mol}^{-1} \mathrm{~K}^{-1}\right), K_{\mathrm{c}}\left(q_{\mathrm{e}} / C_{\mathrm{e}}\right)$ is equilibrium constant at different temperatures, and $T$ is the absolute temperature (K). Eqn (11) calculates $\Delta G^{0}$ values assigning to the obtained temperature shown in Table 2 .

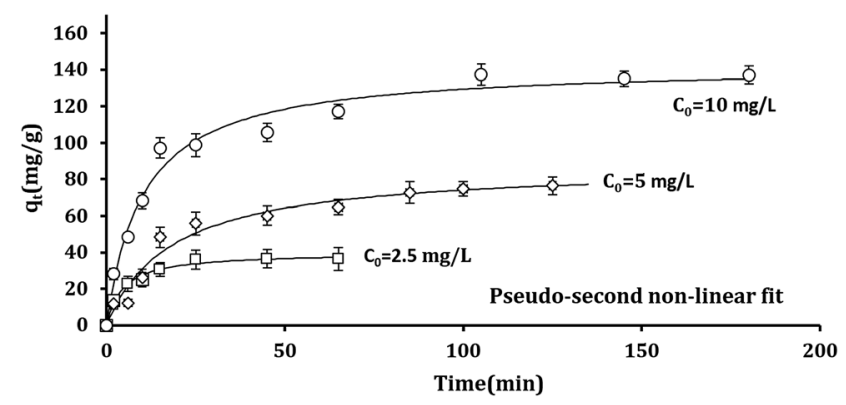

Fig. 6 Nonlinear forms of pseudo-second kinetic model fitted on experimental points at different $\mathrm{Pb}^{2+}$ initial concentrations (adsorbent dosage $100 \mathrm{mg} \mathrm{g}^{-1}$; volume of solution $100 \mathrm{~mL}$; $\mathrm{pH} \mathrm{7;} T=298 \mathrm{~K}$ ). 
Table 2 Thermodynamic parameters for the adsorption of $\mathrm{Pb}^{2+}$ onto the $\mathrm{Fe}_{3} \mathrm{O}_{4}$ (aDHAQ_GO nanocomposite (adsorbent dosage $55 \mathrm{mg} \mathrm{L}^{-1}$, contact time $60 \mathrm{~min}, \mathrm{pH}$ 7)

\begin{tabular}{llllll}
\hline$T$ & $K_{\mathrm{L}}\left(\mathrm{L} \mathrm{g}^{-1}\right)$ & $q_{\mathrm{m}}\left(\mathrm{mg} \mathrm{g}^{-1}\right)$ & $\begin{array}{l}\Delta G^{0}(\mathrm{~kJ} \\
\left.\mathrm{mol}^{-1}\right)\end{array}$ & $\begin{array}{l}\Delta S^{0}(\mathrm{~J} \\
\left.\mathrm{mol}^{-1} \mathrm{~K}\right)\end{array}$ & $\begin{array}{l}\Delta H^{0}(\mathrm{~kJ} \\
\left.\mathrm{mol}^{-1}\right)\end{array}$ \\
\hline 278 & 0.388 & 200.7 & -13.79 & 135.97 & 24.07 \\
293 & 0.598 & 239.4 & -15.58 & - & - \\
308 & 1.178 & 225.3 & -18.12 & - & - \\
323 & 1.546 & 243.1 & -19.73 & - & - \\
\hline
\end{tabular}

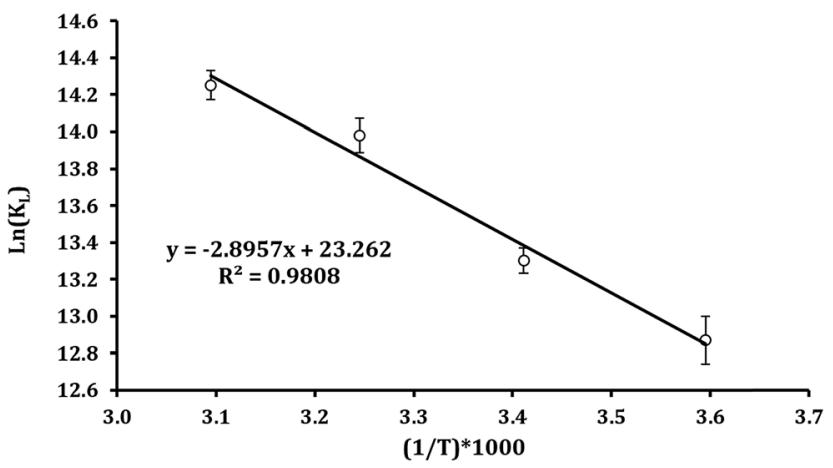

Fig. 7 Effect of temperature on the adsorption of $\mathrm{Pb}^{2+}$ ions by $\mathrm{Fe}_{3}-$ $\mathrm{O}_{4} @ \mathrm{QDHAQ}$ _GO nanocomposite.

Enthalpy $\left(\Delta H^{0}\right)$ and entropy $\left(\Delta S^{0}\right)$ can be determined by plotting $\ln \left(K_{\mathrm{c}}\right)$ versus $1 / T$ as revealed in Fig. 7. Furthermore, $\left(\Delta H^{0}\right)$ and $\left(\Delta S^{0}\right)$ can obtained be from the slope and intercept of linear form of eqn (12), respectively. ${ }^{64-66}$

Table 2 represents that $\Delta G^{0}$ has negative amounts assigning to different temperatures. So, it can be concluded that $\mathrm{Pb}^{2+}$ adsorption on $\mathrm{Fe}_{3} \mathrm{O}_{4} @$ DHAQ_GO nanocomposite proceeds spontaneously.

Fan et al. (2013) found that obtained $\Delta G^{0}$ is ranged from -10.26 to $-16.24 \mathrm{~kJ} \mathrm{~mol}^{-1}$ at $303-323 \mathrm{~K} .^{67}$ Also, Kumar et al. (2014) reported that the changes of free energy $\Delta G^{0}$ at $298 \mathrm{~K}$ are $-6.46 \mathrm{~kJ} \mathrm{~mol}^{-1}$. As shown in Table $2, \Delta G^{0}$ is $-19.73 \mathrm{~kJ} \mathrm{~mol}^{-1}$ at $323 \mathrm{~K}$ having an appropriate agreement with the findings of Fan et al. (2013). Similar finding were reported by other researchers. ${ }^{68-70}$
As represented in Table 2, increasing the temperature tends to lower values assigned to $\Delta G^{0}$ confirming that the adsorption is more efficient at the higher temperatures. ${ }^{71,72}$ The enthalpy $\left(\Delta H^{0}\right)$ value was $24.07 \mathrm{~kJ} \mathrm{~mol}^{-1}$ having the positive value of $\Delta H^{0}$ that indicates the endothermic nature of the adsorption. The entropy $\left(\Delta S^{0}\right)$ was obtained with a positive value proving the increase of randomness during $\mathrm{Pb}^{2+}$ adsorption process. ${ }^{73,74}$

\subsection{Selectivity study}

Two independent studies were conducted to evaluate the selectivity properties of $\mathrm{Fe}_{3} \mathrm{O}_{4} @ D H A Q \_G O$ nanocomposite for the separation of $\mathrm{Pb}^{2+}$ ions from aqueous ion matrices. The first one was capturing $\mathrm{Pb}^{2+}$ ions from four different aqueous solutions so that each solution contains $\mathrm{Pb}^{2+}$ and one other divalent metal ion. Consequently, four binary ion matrices were prepared, including $\mathrm{Pb}^{2+} / \mathrm{Cu}^{2+}, \mathrm{Pb}^{2+} / \mathrm{Cd}^{2+}, \mathrm{Pb}^{2+} / \mathrm{Zn}^{2+}$, and $\mathrm{Pb}^{2+} /$ $\mathrm{Co}^{2+}$.

The second study was conducted for the assessment selective removal of $\mathrm{Pb}^{2+}$ in drinking water samples containing natural ion matrices. Certain amounts of $\mathrm{Pb}^{2+}$ ion were spiked into 30 different drinking water samples collected from various groundwater sources. Batch experiments were conducted based on the optimized values of variables $\mathrm{pH}$, dosage, temperature, and the initial concentration.

3.3.1. Selective removal of $\mathrm{Pb}^{2+}$ from binary ion matrices. The above mentioned aliquots containing binary ions were exposed to the functionalized $\left(\mathrm{Fe}_{3} \mathrm{O}_{4} @ \mathrm{DHAQ}\right.$ _GO) and pristine (GO@ $\mathrm{SiO}_{2}-\mathrm{Fe}_{3} \mathrm{O}_{4}$ ) nanocomposite through independent batch experiments. Table 3 shows the results of distribution coefficient $K_{\mathrm{d}}\left(\mathrm{mL} \mathrm{g}^{-1}\right)$, selectivity coefficient $k$, and the relative selectivity coefficient $k$ obtained from eqn (2)-(4), respectively. As observed, the values of selectivity coefficient $k$ is more than 19 for all binary ion comparisons. It means that $\mathrm{Fe}_{3} \mathrm{O}_{4}$ @DHAQ_GO nanocomposite has a more notable preference for capturing $\mathrm{Pb}^{2+}$ ions compared with that of coexistence ions. For instance, $\mathrm{Fe}_{3} \mathrm{O}_{4} @ D H A Q \_G O$ nanocomposite could capture $\mathrm{Pb}^{2+}$ ions 19.66 times more selectively than $\mathrm{Cu}^{2+}$ ions. Cai et al. reported a $k$ value of 11.66 for $\mathrm{Pb}^{2+} / \mathrm{Cu}^{2+}$ binary ions. Furthermore, Msaadi et al. and $\mathrm{Zhu}$ et al. reported similar findings for $\mathrm{Pb}^{2+}$ ions removal using ion-imprinted nanocomposites. ${ }^{75,76}$

3.3.2. Selective removal of $\mathrm{Pb}^{2+}$ from drinking water samples. Table $\mathrm{S} 2 \dagger$ shows a set of multiple regression models

Table 3 Selectivity parameters of $\mathrm{Pb}^{2+}$ comparative loading by $\mathrm{Fe}_{3} \mathrm{O}_{4} @ \mathrm{QDHAQ} \_\mathrm{GO}$ and $\mathrm{Fe}_{3} \mathrm{O}_{4} \mathrm{QSiO}_{2}-\mathrm{GO}$ sorbents at $\mathrm{pH}$, and $T=298 \mathrm{~K}$ (acetic acid/sodium acetate buffer)

\begin{tabular}{|c|c|c|c|c|c|c|c|}
\hline $\mathrm{Cu}^{2+}$ & 15 & 2.16 & & 50 & 8.26 & & \\
\hline $\mathrm{Pb}^{2+}$ & 133 & 36.81 & 31.89 & 37 & 5.74 & 1.34 & 23.72 \\
\hline $\mathrm{Ni}^{2+}$ & 9 & 1.15 & & 30 & 4.27 & & \\
\hline $\mathrm{Pb}^{2+}$ & 119 & 32.38 & 15.09 & 21 & 3.21 & 0.58 & 26.09 \\
\hline $\mathrm{Cd}^{2+}$ & 15 & 2.15 & & 35 & 5.54 & & \\
\hline
\end{tabular}


Table 4 Ranking list of linear multiple regression models applied to describe the effect of main natural water ions on mercury removal efficiency by Akaike's Information Criterion (AIC)

\begin{tabular}{lcccll}
\hline $\begin{array}{l}\text { Model } \\
\text { elements }\end{array}$ & Coefficient & $\begin{array}{l}\text { Standard } \\
\text { error }\end{array}$ & $T$ value & $\operatorname{Pr}(>|t|)$ & $P$-value \\
\hline Intercept & 105.47 & 5.23 & 20.15 & 0.0001 & 0.001 \\
$\mathrm{NO}_{3}{ }^{-}$ & $0.70(\mathrm{a})$ & 0.43 & 1.62 & 0.120 & 0.1 \\
$\mathrm{SO}_{4}{ }^{2-}$ & $0.17(\mathrm{~b})$ & 0.05 & 2.8 & 0.009 & 0.001 \\
$\mathrm{Cl}^{-}$ & $0.31(\mathrm{c})$ & 0.08 & 3.66 & 0.001 & 0.001 \\
$\mathrm{HCO}_{3}{ }^{-}$ & $0.15(\mathrm{~d})$ & 0.04 & 3.51 & 0.002 & 0.001 \\
$\mathrm{Na}^{+}$ & $-0.29(\mathrm{e})$ & 0.14 & -1.95 & 0.064 & 0.05 \\
$\mathrm{~K}^{+}$ & $-0.47(\mathrm{f})$ & -0.27 & -1.75 & 0.093 & 0.05 \\
$\mathrm{Mg}^{2+}$ & $-1.15(\mathrm{~g})$ & -0.29 & -3.89 & 0.0008 & 0.001 \\
$\mathrm{Ca}^{2+}$ & $-0.73(\mathrm{~h})$ & -0.15 & -4.69 & 0.0001 & 0.001
\end{tabular}

${ }^{a}$ Multiple $R^{2}: 0.81$, adjusted $R^{2}: 0.73$.

ranked according the Akaike's Information Criterion (AIC). Table 4 represents the coefficients of the model obtained rank 1 in Table S2. $\dagger$ As observed, cations formed the drinking water matrices $\left(\mathrm{Na}^{+}, \mathrm{K}^{+}, \mathrm{Ca}^{2+}, \mathrm{Mg}^{2+}\right)$ obtained negative values confirming their competition with $\mathrm{Pb}^{2+}$ ion to occupy the active sites of $\mathrm{Fe}_{3} \mathrm{O}_{4} @ D H A Q \_G O$ nanocomposite. The large value assigned to the intercept (105.47) ensured notable preference of $\mathrm{Fe}_{3} \mathrm{O}_{4} @ D H A Q$ GO nanocomposite for the separation of $\mathrm{Pb}^{2+}$ ion from drinking water.

\subsection{Desorption and regeneration}

Fig. 8(a) depicts the repeated adsorption/desorption of $\mathrm{Pb}^{2+}$ ions using batch experiments exposed with $\mathrm{Fe}_{3} \mathrm{O}_{4} @$ @HAQ_GO nanocomposite in single ion aqueous solution. As shown, after 5 consecutive regeneration steps, the nanocomposite could remove 86 percent of $\mathrm{Pb}^{2+}$ ions so that only 12 percent of removal loss was observed.

Fig. 8(b) shows the results of $\mathrm{Fe}_{3} \mathrm{O}_{4} @ D H A Q$ GO regeneration study in an aqueous ion matrix consisting of five divalent metals. This experiment aims to investigate the presence of four coexistence ions $\left(\mathrm{Cu}^{2+}, \mathrm{Ni}^{2+}, \mathrm{Co}^{2+}, \mathrm{Cd}^{2+}\right)$ in the case of their effect on lead removal and to assess the capability of the nanocomposite for the retaining of lead adsorption capacity after several washing steps in the presence of other cations. As observed, the removal capacities of $\mathrm{Pb}^{2+}$ ion was remained more than $111 \mathrm{mg} \mathrm{g}^{-1}$ over five regeneration steps using the desorption agent EDTA-2NA 0.01 N. Furthermore, increasing the sorption capacity assigned to the four coexistence ions were almost negligible confirming the notable stability of the nanocomposite structure over several regeneration experiments.

The stability of the $\mathrm{Pb}^{2+}$ and $\mathrm{Fe}_{3} \mathrm{O}_{4} @$ @DHAQ_GO complex was confirmed via the adsorption/desorption experiments. The conventional methods for evaluating the regeneration and reusability of adsorbents are according to the consecutive adsorption/desorption steps in batch volumes containing deionized water solution inoculated with the target pollutant. Consequently, the effects of coexistence ions are neglected, especially when the reusability of adsorbents having selectivity properties is considered. ${ }^{77}$
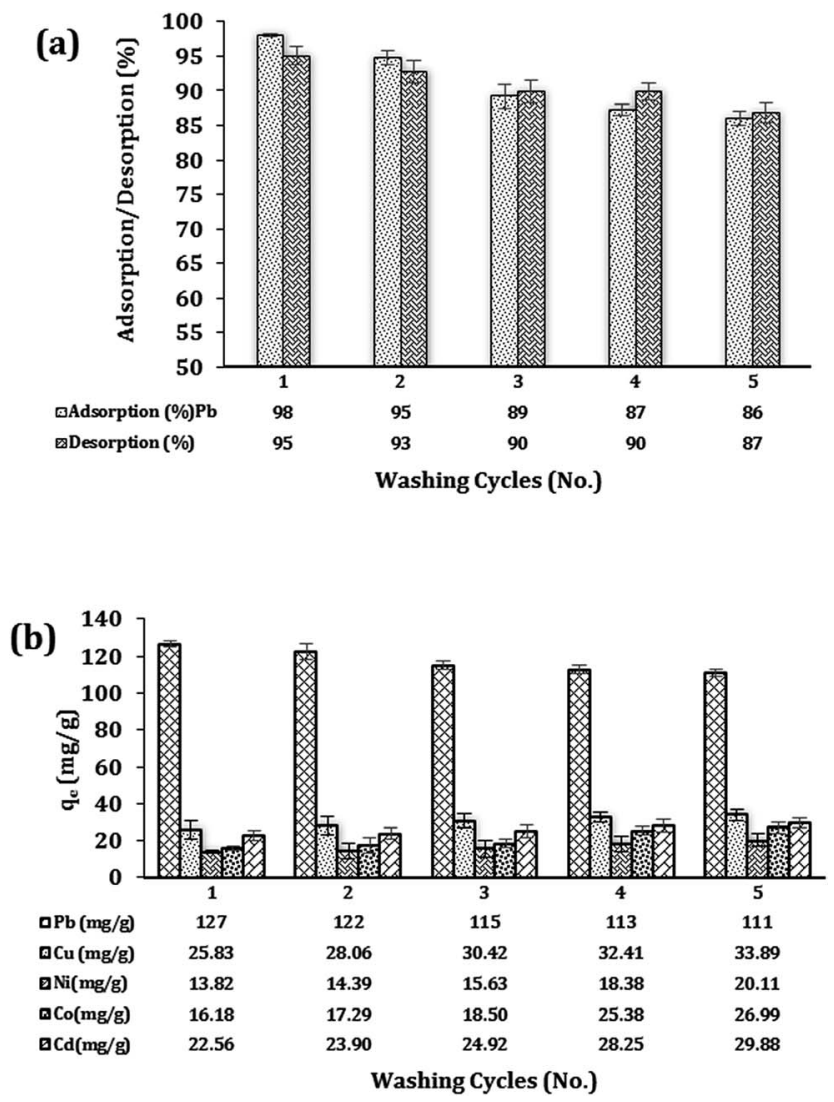

Fig. 8 Reusability studies; repeated adsorption/desorption of $\mathrm{Pb}^{2+}$ by $\mathrm{Fe}_{3} \mathrm{O}_{4} @ \mathrm{QDHAQ}_{-} \mathrm{GO}$ nanocomposite (a). The consecutive adsorption capacities $\left(\mathrm{mg} \mathrm{g}^{-1}\right.$ ) of $\mathrm{Fe}_{3} \mathrm{O}_{4}(\mathrm{aDHAQ} \mathrm{GO}$ nanocomposite for $\mathrm{Pb}(\Perp)$, $\mathrm{Cu}(॥), \mathrm{Ni}\left({ }^{\prime}\right), \mathrm{Co}(॥)$, and $\mathrm{Cd}(॥)$ ions during the five adsorption/desorption cycles (b). $C_{0} \simeq 50 \mathrm{mg} \mathrm{L}^{-1}$, adsorbent dosage $=0.4 \mathrm{~g} \mathrm{~L}^{-1}, \mathrm{pH} 7$, contact time $30 \mathrm{~min}$, desorption agent: EDTA-2Na $0.01 \mathrm{~N}$.

Here, we put forward a facile approach to investigate the reusability of $\mathrm{Fe}_{3} \mathrm{O}_{4} @$ DHAQ_GO in aqueous ion matrices containing different competitor divalent cations (Fig. 8). Yu et al. reported applying EDTA-2Na $0.015 \mathrm{~N}$ as washing agent over three cycles regeneration steps. Results showed the notable interference of $\mathrm{Cd}^{2+}$ (ref. 78) while, in our work, the minimum interfering of the coexistence cations was observed.

\section{Conclusions}

In this work, a novel hydrophilic nanocomposite based on GO was synthesized comprising an anthraquinone derivative having selective removal capability for lead. $\mathrm{Fe}_{3} \mathrm{O}_{4}$ nanoparticles was used as a magnetic agent to facilitate the separation of nanocomposite from aqueous solution. Also, GO was used as a dispersible platform to obtain the hydrophilic property for the nanocomposite and preparing enough surface area to proceed the adsorptive mechanisms. The morphology and structure of the obtained adsorbent was characterized by UV-Vis, FT-IR, SEM, XRD, and TGA. The synthesis rout was simple and DHAQ was an environmental friendly compound without toxic effect. The selectivity characteristics of the nanocomposite was 
evaluated through two different methods including controlled ion matrices and the natural ion matrices obtained from drinking water samples. Furthermore, the regeneration and reusability studies were conducted in the presence of coexistence ions. It seems that $\mathrm{Fe}_{3} \mathrm{O}_{4} @ D H A Q$ GO nanocomposite can be a promising selective removal agent for the removal of lead from polluted waters and industrial discharges.

\section{Conflicts of interest}

There are no conflicts to declare.

\section{Acknowledgements}

This research was part of a PhD dissertation of the first author and has been financially supported by a grant (No. 28232-27-0194) from Tehran University of Medical Sciences, Tehran, Iran. The authors would like to express their thanks to the Department of Environmental Health Engineering, School of Public Health, Tehran University of Medical Sciences for their collaboration.

\section{References}

1 M. Khazaei, S. Nasseri, M. R. Ganjali, M. Khoobi, R. Nabizadeh, A. H. Mahvi, S. Nazmara and E. Gholibegloo, J. Environ. Health Sci. Eng., 2016, 14, 1.

2 WHO, Journal, 2003.

3 EPA, Drinking Water Contaminants, http://www.epa.gov/ safewater/contaminants/index.html, 1/30/2010., (accessed 9/13/2015, 2015).

4 ISIRI, Journal, 2014.

$5 \mathrm{H}$. Karimi, International Journal of Water and Wastewater Treatment, 2017, 3.

6 Q. Li, T. Liu and P. Deng, in, Characterization of Minerals, Metals, and Materials, Springer, 2015, pp. 667-674.

7 R. Kamaraj, P. Ganesan and S. Vasudevan, Int. J. Environ. Sci. Technol., 2015, 12, 683-692.

8 S. Vasudevan, J. Lakshmi and G. Sozhan, Environ. Sci. Pollut. Res., 2012, 19, 2734-2744.

9 E. Aliyari, M. Alvand and F. Shemirani, Anal. Methods, 2015, 7, 7582-7589.

10 S. K. Ghadiri, S. Nasseri, R. Nabizadeh, M. Khoobi, S. Nazmara and A. H. Mahvi, J. Mol. Liq., 2017, 242, 11111117.

11 A. Gholami, A. Moghadassi, S. Hosseini, S. Shabani and F. Gholami, J. Ind. Eng. Chem., 2014, 20, 1517-1522.

12 R. Rezaee, S. Nasseri, A. Mahvi, R. Nabizadeh, S. Mousavi, A. Rashidi, A. Jafari and S. Nazmara, J. Environ. Health Sci. Eng., 2015, 13, 1-11.

13 C. J. Madadrang, H. Y. Kim, G. Gao, N. Wang, J. Zhu, H. Feng, M. Gorring, M. L. Kasner and S. Hou, ACS Appl. Mater. Interfaces, 2012, 4, 1186-1193.

14 P. Ganesan, R. Kamaraj, G. Sozhan and S. Vasudevan, Environ. Sci. Pollut. Res., 2013, 20, 987-996.

15 W. Li, S. Gao, L. Wu, S. Qiu, Y. Guo, X. Geng, M. Chen, S. Liao, C. Zhu and Y. Gong, Sci. Rep., 2013, 3, 2125.
16 J. Kim, L. J. Cote and J. Huang, Acc. Chem. Res., 2012, 45, 1356-1364.

17 J. Kim, L. J. Cote, F. Kim, W. Yuan, K. R. Shull and J. Huang, J. Am. Chem. Soc., 2010, 132, 8180-8186.

18 J. Paredes, S. Villar-Rodil, A. Martinez-Alonso and J. Tascon, Langmuir, 2008, 24, 10560-10564.

19 M. J. Gismera, M. T. Sevilla and J. R. Procopio, Anal. Sci., 2006, 22, 405.

20 N. Tavakkoli, Z. Khojasteh, H. Sharghi and M. Shamsipur, Anal. Chim. Acta, 1998, 360, 203-208.

21 M. Rezayi, R. Karazhian, Y. Abdollahi, L. Narimani, S. B. T. Sany, S. Ahmadzadeh and Y. Alias, Sci. Rep., 2014, 4.

22 M. Barzegar, M. F. Mousavi, H. Khajehsharifi, M. Shamsipur and H. Sharghi, IEEE Sens. J., 2005, 5, 392-397.

23 X.-G. Li, X.-L. Ma and M.-R. Huang, Talanta, 2009, 78, 498505.

24 A. Goswami and A. K. Singh, Talanta, 2002, 58, 669-678.

25 T. Alizadeh, N. Hamidi, M. R. Ganjali and F. Rafiei, J. Environ. Chem. Eng., 2017, 5, 4327-4336.

26 X. Niu, Y. Zhong, R. Chen, F. Wang, Y. Liu and D. Luo, Sens. Actuators, B, 2018, 255, 1577-1581.

27 Z. Zhang, D. Shi, H. Ding, H. Zheng and H. Chen, Int. J. Environ. Sci. Technol., 2015, 12, 3351-3362.

28 Y. Shen, Q. Xu, D. Gao and H. Shi, Ozone: Sci. Eng., 2017, 39, 219-232.

29 W. S. Hummers Jr and R. E. Offeman, J. Am. Chem. Soc., 1958, 80, 1339.

$30 \mathrm{H}$. Hamadi, M. Gholami and M. Khoobi, International Journal of Heterocyclic Chemistry, 2011, 1, 23-34.

31 P. Tartaj and C. J. Serna, J. Am. Chem. Soc., 2003, 125, 1575415755.

32 F. He, J. Fan, D. Ma, L. Zhang, C. Leung and H. L. Chan, Carbon, 2010, 48, 3139-3144.

33 L. J. Cote, F. Kim and J. Huang, J. Am. Chem. Soc., 2008, 131, 1043-1049.

34 M. A. Hossain, H. H. Ngo and W. Guo, J. Water Sustainability, 2013, 3, 223-237.

35 F.-y. Wu, M.-h. Hu, Y.-m. Wu, X.-f. Tan, Y.-q. Zhao and Z.-j. Ji, Spectrochim. Acta, Part A, 2006, 65, 633-637.

36 M. M. Hoffman, A. B. Kryjevski, A. G. Sykes and D. S. Kilin, Mol. Phys., 2016, 114, 562-575.

37 S. Riahi, M. Mousavi, M. Shamsipur and H. Sharghi, Electroanalysis, 2003, 15, 1561-1565.

38 H. Reza Pouretedal, A. Forghaniha, H. Sharghi and M. Shamsipur, Synth. React. Inorg. Met.-Org. Chem., 1998, 31, 2591-2605.

39 G. I. Titelman, V. Gelman, S. Bron, R. L. Khalfin, Y. Cohen and H. Bianco-Peled, Carbon, 2005, 43, 641-649.

40 S. Stankovich, R. D. Piner, S. T. Nguyen and R. S. Ruoff, Carbon, 2006, 44, 3342-3347.

41 S. D. Abkenar, M. Khoobi, R. Tarasi, M. Hosseini, A. Shafiee and M. R. Ganjali, J. Environ. Eng., 2014, 141, 04014049.

42 F. Cataldo, Fullerenes, Nanotubes, Carbon Nanostruct., 2003, 11, 1-13.

43 X. Sun, Z. Liu, K. Welsher, J. T. Robinson, A. Goodwin, S. Zaric and H. Dai, Nano Res., 2008, 1, 203-212. 
44 X. Yang, Y. Wang, X. Huang, Y. Ma, Y. Huang, R. Yang, H. Duan and Y. Chen, J. Mater. Chem., 2011, 21, 3448-3454.

45 Y. Xu, Z. Liu, X. Zhang, Y. Wang, J. Tian, Y. Huang, Y. Ma, X. Zhang and Y. Chen, Adv. Mater., 2009, 21, 1275-1279.

46 Y. Li, X.-Y. Wang, X.-P. Jiang, J.-J. Ye, Y.-W. Zhang and X.-Y. Zhang, J. Nanopart. Res., 2015, 17, 1-12.

47 G. Zhao, X. Ren, X. Gao, X. Tan, J. Li, C. Chen, Y. Huang and X. Wang, Dalton Trans., 2011, 40, 10945-10952.

48 M. Khazaei, S. Nasseri, M. R. Ganjali, R. Nabizadeh, A. H. Mahvi, E. Gholibegloo, M. Khoobi and S. Nazmara, Desalin. Water Treat., 2017, 83, 144-158.

49 S. Stankovich, D. A. Dikin, R. D. Piner, K. A. Kohlhaas, A. Kleinhammes, Y. Jia, Y. Wu, S. T. Nguyen and R. S. Ruoff, Carbon, 2007, 45, 1558-1565.

50 G. A. Broker, R. P. A. Bettens and E. R. T. Tiekink, CrystEngComm, 2008, 10, 879-887.

51 E. Aliyari, M. Alvand and F. Shemirani, $R S C A d v ., 2016,6$, 64193-64202.

52 M. Tarlani Azar, M. Leili, F. Taherkhani and A. Bhatnagar, Desalin. Water Treat., 2016, 57, 24430-24443.

53 S. Stankovich, D. A. Dikin, G. H. Dommett, K. M. Kohlhaas, E. J. Zimney, E. A. Stach, R. D. Piner, S. T. Nguyen and R. S. Ruoff, Nature, 2006, 442, 282-286.

54 E. Repo, J. K. Warchol, T. A. Kurniawan and M. E. T. Sillanpää, Chem. Eng. J., 2010, 161, 73-82.

55 L. Guo, G. Li, J. Liu, P. Yin and Q. Li, Ind. Eng. Chem. Res., 2009, 48, 10657-10663.

56 E. Repo, J. K. Warchoł, A. Bhatnagar and M. Sillanpää, J. Colloid Interface Sci., 2011, 358, 261-267.

57 E. Repo, Doctor of Science, Lappeenranta University of Technology Laboratory of Green Chemistry, 2011.

58 Y. Ma, P. La, W. Lei, C. Lu and X. Du, Desalin. Water Treat., 2016, 57, 5004-5012.

59 A. Dalvand, E. Gholibegloo, M. R. Ganjali, N. Golchinpoor, M. Khazaei, H. Kamani, S. S. Hosseini and A. H. Mahvi, Environ. Sci. Pollut. Res., 2016, 23, 16396-16405.
60 S. Vasudevan and J. Lakshmi, Water Sci. Technol.: Water Supply, 2011, 11, 142-150.

61 Y. S. Ho and G. McKay, Process Biochem., 1999, 34, 451-465.

62 R. Kamaraj, D. J. Davidson, G. Sozhan and S. Vasudevan, J. Taiwan Inst. Chem. Eng., 2014, 45, 2943-2949.

63 S. Vasudevan, J. Lakshmi, R. Kamaraj and G. Sozhan, AsiaPac. J. Chem. Eng., 2013, 8, 162-171.

64 Z.-Y. Yao, J.-H. Qi and L.-H. Wang, J. Hazard. Mater., 2010, 174, 137-143.

65 S. Vasudevan and J. Lakshmi, Can. J. Chem. Eng., 2012, 90, 1017-1026.

66 M. Naushad, S. Vasudevan, G. Sharma, A. Kumar and Z. ALOthman, Desalin. Water Treat., 2016, 57, 18551-18559.

67 L. Fan, C. Luo, M. Sun, X. Li and H. Qiu, Colloids Surf., B, 2013, 103, 523-529.

68 H. Hadi Najafabadi, M. Irani, L. Roshanfekr Rad, A. Heydari Haratameh and I. Haririan, RSC Adv., 2015, 5, 16532-16539.

69 Y. Zhang, L. Yan, W. Xu, X. Guo, L. Cui, L. Gao, Q. Wei and B. Du, J. Mol. Liq., 2014, 191, 177-182.

70 R. Kamaraj, D. J. Davidson, G. Sozhan and S. Vasudevan, RSC Adv. , 2015, 5, 39799-39809.

71 E. Unuabonah, K. Adebowale and B. Olu-Owolabi, J. Hazard. Mater., 2007, 144, 386-395.

72 R. Kamaraj, A. Pandiarajan, S. Jayakiruba, M. Naushad and S. Vasudevan, J. Mol. Liq., 2016, 215, 204-211.

73 Y.-H. Li, Z. Di, J. Ding, D. Wu, Z. Luan and Y. Zhu, Water Res., 2005, 39, 605-609.

74 S. Vasudevan and J. Lakshmi, Environ. Eng. Sci., 2012, 29, 563-572.

75 L. Zhu, Z. Zhu, R. Zhang, J. Hong and Y. Qiu, J. Environ. Sci., 2011, 23, 1955-1961.

76 R. Msaadi, S. Ammar, M. M. Chehimi and Y. Yagci, Eur. Polym. J., 2017, 89, 367-380.

77 J. Yu, J. Zheng, Q. Lu, S. Yang, X. Zhang, X. Wang and W. Yang, Colloid Polym. Sci., 2016, 294, 1585-1598.

78 J. Yu, J. Zheng, Q. Lu, S. Yang, X. Wang, X. Zhang and W. Yang, Iran. Polym. J., 2016, 25, 1009-1019. 